\title{
Strengthening Pela-Gandong Alliance Based on John Rawls' Theory of Justice
}

\author{
Juanrico A.S. Titahelu ${ }^{1}$, Irwansyah ${ }^{2}$, Hamid Awaludin ${ }^{3}$, Muhammad Ashri ${ }^{4}$ \\ ${ }^{1}$ Fakultas Hukum Universitas Pattimura \\ Jn. Ir. M. Putuhena, Ambon, 97233, Maluku \\ Tel./Fax: +62-911-3825204 E-mail: juanricotitahelu@yahoo.com \\ ${ }^{2}$ Fakultas Hukum Universitas Hasanuddin \\ Jln. Perintis Kemerdekaan Km. 10, Tamalanrea, Makassar, 90245, Sulawesi Selatan \\ Tel./Fax: +62-411-587219 E-mail: irwansyahrawydharma@yahoo.com \\ ${ }^{3}$ Fakultas Hukum Universitas Hasanuddin \\ Jln. Perintis Kemerdekaan Km. 10, Tamalanrea, Makassar, 90245, Sulawesi Selatan \\ Tel./Fax: +62-411-587219 E-mail: awaludinhamid@hotmail.com \\ ${ }^{4}$ Fakultas Hukum Universitas Hasanuddin \\ Jln. Perintis Kemerdekaan Km. 10, Tamalanrea, Makassar, 90245, Sulawesi Selatan \\ Tel./Fax: +62-411-587219 E-mail: $\underline{m \text { ashri@hotmail.com }}$ \\ Submitted: Oct 7, 2015; Reviewed: Nov 21, 2015; Accepted: Nov 28, 2015
}

\begin{abstract}
Pela-Gandong could be seen as an alliance among two or more villages in Central Maluku territory. Pela-Gandong, besides as brotherhood and friendship among them,this alliance also shared common purpose of cooperation and collective security. Conflict in the beginning of 1999 draws up public attention to the effectiveness of the principles which contains in pela-gandong alliance. Important question come forward because of the plurality condition among current Indonesian society. Should pela-gandong principles nowadays, still playing role to develope social, economy and cultural life of Maluku traditional society? The purpose of this writings is to find out the weaknesses of pela-gandong alliance(s). Based on this, it should offers some suggestion how to strengthening the principles of pela-gandong alliance into the state and the social life in Indonesia.
\end{abstract}

Keywords: Pela-Gandong; Local Wisdom; Legal Principle; Legal End

\section{INTRODUCTION}

Pela-gandong, ranging public concern in Indonesia since the last few years, especially when there were riots in Ambon and surrounding areas in 1999-2004. Special scientific research on the relationship pelagandong conducted by Diter Bartel. ${ }^{1}$ Pela-

1 Diter Bartels. (1977). Guarding the Invisible Mountain: Intervillage Alliances, Religious Syncretism and Ethnic Identity among Ambonese gandong is the relationship between the citizens of two or more villages ${ }^{2}$ in Central

Christians and Moslems in the Moluccas. Ithaca, NY: Cornell University.

2 The term village or in the literature customary law called "negeri" is the designation for the overall area of the region that includes the land, (settlements, agricultural lands, mountains or hills, pastures, grassland, forests), rivers, seaside or coastal sea to sea waters at certain depths, controlled, possessed, and used by the communion of Indigenous People in that place. 
Maluku. ${ }^{3}$ Mentioned by Bartel that pelagandong is an alliance system in the form of a local wisdom in fraternal bond, or bonds of friendship. ${ }^{4}$ Alliance formed accompanied by magical or religious ties.

Briefly, pela-gandong can be described as an alliance between the villages whose inhabitans are generally embrace different religions. Pela-gandong consists of the entire villagers who are Muslim, with the villagers who are all Christians. First, alliance in the form of the fraternity known as gandong. Gandong word comes from the word "womb". Meaning, two or more villages that are in this alliance bond comes from the same womb. These relationship is called Gandong, their villages also greet each others with term "gandong", or bongso (often said "bonso"). For example, the relationship between bongso or bonso Tamilouw village (villagers are Muslim) in Seram, with Siri Sori Serani, Pia village (Christian villagers) in the island of Saparua, and Hutumuri village (Christian villagers) in Ambon island. Gandong alliance between Naku village (Christian villagers in Ambon island) with Larike (Christian villagers in Ambon island), the Ema village (Christian villagers in Ambon island) with Batu Merah village (Muslim villagers in the Ambon island); Second, Pela is not just friendship or a regular communion. Pela are also a form of fraternity (brotherhood), although each Pela pair not come

Intended as the Middle Moluccas in this paper is the geographical area that includes the island of Seram, Ambon island, Haruku island, the island Saparua and Nusalaut. Thus, Central Maluku designation in this writing is not in the sense of region in govermental administration.

4 Bartels, D. (without year). Pela Alliances in the Central Moluccas and in the Netherlands: A Brief Guide for Beginners. from the same womb. Wasisto Raharjo Jati ${ }^{5}$ explaining, "Pela.. usually done in the form of a ceremony of drinking wine mixed with blood of the two leaders of the villages..." indicate a Pela relationship between the two villages and binding its offspring of all time. Pela-gandong symbolized as siblings relationship between both villages. For example, in such alliances between the village of Oma (Christians on the Haruku island) with Ulath (Christians on the Saparua island), and Buano (Muslim, a small island on the western side of Seram island). Alliances between the village of Ema (Christian in the Ambon island) with Ameth (Christians on the Nusa Laut island), and the Naku (Christians on the Ambon island) and Batu Merah village with Passo. Pela between Siri-sori Salam (all villagers are Muslim) on the island of Saparua, with Haria (all villagers are Christian) which also on the island of Saparua. Another example, Pela between Ori (all villagers are Muslim on the island Haruku, with Tuhaha (all villagers are Christians) on the island of Saparua.

This alliance system has been formed long before the arrival of Europeans (Portugal, Netherlands to look for spices cloves and nutmeg) on the 16th and 17 th centuries. Process, time and purpose of the alliance of pela-gandong are varies between one of others:

1. Presented by Bartel that initially the alliance system is intended to prevent intrusion of outsiders into the allied countries.

\footnotetext{
5 Wasisto Raharjo Jati. (2013). "Kearifan Lokal Sebagai Resolusi Konflik Keagamaan". Jurnal Walisongo, 21(2): 393 - 416.
} 
2. Another goal is to help each other to fight the enemy force. The term is still remembered by the elders, based on said hereditary. The aid is reinfforcements. These reinforcements needed when a village facing a war between villages.

3. In a further development, new Pela alliances were emerged to utilized against the Dutch colonial government, especially during the struggle Pattimura. When the war between villages, or even the war against the Dutch subsided, then the purpose to help in giving reinforcements turned into an act of mutual help in meeting the specific needs. Timber generally used to build a worship house. Besides the help that is created is also in the form of aid workers. For example is the Pela relationship between Ihamahu (Christians village on the island of Saparua) with Amahai (Christians village on the island of Seram $)^{6}$.On October 2nd, 2009 in the presence of the Governor of Maluku, Pela relationship between Kailolo village (island Haruku) and Tihulale (on the island of Seram) just get tightened. The alliance is marked as Pela brother. It is said that the story in the days of Dutch colonial rule, a mutually beneficial relationship between both villages began to be created. In 1921 when the boat race striped performed by the Dutch government, both countries are

6 From the information obtained, alliances between the villages Ihamahu and Amahai, took place in 1899-1900 happens because of an earthquake and devastating tsunami, which claimed the lives of so many.Pela relationship between Ihamahu and Amahai, marked by a church ceremony. in a team. The team managed to win the race. Since then, a close relationship between the two countries created. Familiarity it looked at the time country Kailolo build a mosque Nan Datu. Kailolo village invited Tihulale village to be present. Tihulale village came with the building materials such as wood and boards that will be used in the construction of mosques. A few years later the Tihulale village doing construction for Beth Eden Church. Kailolo, then come and bring donations of ceramics.

4. In further developments, the relationship of pela-gandong also have a purpose to ease tensions if the conflict occurs among the villagers.

Pela-Gandong alliance marked with different characteristic: Firstly, Pela alliance with hard characteristic, or so-called "hard pela", "pela-batu karang" (or rock-pela), also "pela tuni", "pela sejati" or "pela darah" (or blood pela). Meaning, this pela characterized by drink the blood of each party that are dropped into wine or gin (a traditional alcoholic drink distilled from palm wine). This Pela does not allow termination, given the oath of progenitor/ancestors that anyone who violated the customary oath will receive customary sanction. ${ }^{7}$ In addition, the hard pelacharacterized alsoby the prohibition of mating between the parties involved in oath. ${ }^{8}$

\footnotetext{
Johra Holle. (2007). Peranan "Pela" dalam Memelihara Toleransi Umat Beragama Pasca Konflik di Kecamatan Saparua serta Implikasinya Terhadap Ketahanan Wilayah Kabupaten Maluku Tengah Provinsi Maluku. (Tesis). Yogyakarta: Universitas Gadjah Mada.

8 Diter Bartel. Alliances Without Marriage: Exogamy, Economic Exchange, and Symbolic Unity Among Ambonese Christian and Moslems. Compare with
} 
Secondly, there is an alliance that is aligned with the so-called "pela tampa sirih". Such alliances are more of a friendship. Even if the bond or alliance is also performed by swearing as was done in the hard pela, but there relationship is more friendship. There is no mating prohibition between the villagers s of the alliance. Thirdly, land or villages alliance called gandong, bongso (bonso) although not confirmed by the ceremony of drinking gin mixed with blood of the alliance members' leaders, but the marriage among gandong alliance members is highly prohibited.

Among the countries that have alliances as noted above, are often carried out " $\mathrm{Pa}$ nas Pela" activity with purpose to retighten the pela-gandong relationship. The activity is not an annual program, also the place is chosen in rotation. From the brief description above, it appears that pela or gandong alliance are generally built on the thesis: 1) The need to help each other both physically and materially to achieve the goals of security and development; 2) The need for maintaining harmony among the citizens of the villages of pela-gandong; and 3) The need to ease tensions, when faced with a conflict between their respective villagers.

The description above were transformed by the author into two main problems: First, is the need of mutual assistance limited only to meet the needs of the physical and material required at any time? Second, is a harmonious life and relieve tension only apply between allied countries? In times of conflict between the years 1999-2004, the question arises to what extent, culture of

Kevin Tuhumury. (2011). Melihat Pela Kawin Antar Negeri Latuhalat dan Allang Dilihat Dari Sudut Teologi Kontekstual. pela-gandong itself act as the instrument to maintain harmonious relations among citizens, when certain factors affect people's lives in Central Maluku. M. Attamimy said that after the riots in Ambon, appear a desire to re-establish a civilized society. It is believed that the spirit of pela-gandong still able to strengthen the brotherhood. Another thing that needs to be developed is how to strengthen pela-gandong alliances into alliances that play a role in achieving a prosperous life together.

Problems as mentioned above, used as matters of law as follows: 1) How big is the local culture and strengthening pelagandong can guarantee legal purposes in the form of expediency, legal certainty (in the sense of law and order), and justice in the Maluku? 2) Is the principles of pela-gandong relationship can be expanded to the countryliving principles and structure of living in a pluralistic and open society today?

The aim of this study is to assess on how far the principles of pela-gandong principles among allied villages, can be applied also for the villages or units of other Indigenous People outside the alliance, which exist in all parts of Maluku. Starting from the implementation power of pela-gandong alliance in current situation, proposing a suggestion that the principle of pela-gandong may gain strength of law (rechtsverwerking) that encourages the purposes of law within the broader scope of the statutory objectives of each party allied in pela-gandong. Furthermore in order to apply the power and usefulness of the principles pela-gandong can be extended to communities of other people who are in the Maluku. Instead, make the 
principles of pela-gandong can be adapted by Maluku communities that are outside the Maluku, and can be synergized with the cultural unity of the local communities where they are located. The study was conducted by descriptive aanalysis to seek legal principles and purposes of the law contained in pela-gandong alliance.

\section{ANALYSIS AND DISCUSSION}

Sukarno Aburarera and few of his collagues, extracting opinion of John Rawls in his Theory of Justice that equality in John Rawls theory of justice is based on the basic view that, "justice as the primary virtue that must be adhered to and also become the basis of a community spirit. Treats justice as the primary virtue, means providing a fair and equal opportunity for everyone to develop and enjoy the self-esteem and dignity as human beings that can not be measured with economic wealth characterized by freedom established by contract approach." 9

From the quotation above, found the process of achieving justice, with the "aim of giving fair and equal opportunity for everyone." It was done through the opportunities to approach or process the contract, and the purpose of performing the contract or agreement is to develop self-esteem, develop their dignity; enjoying his self-esteem; and enjoy dignity.

In the process of forming pela-gandong alliance, the opportunity to do a deal occurs when each party has a need that can be obtained from its alliance partner. Approach or the contracting process is based on the desire

$9 \quad$ Sukarno Aburaera et al. (2009). Filsafat Hukum Jakarta: Kencana Prenada Media, page 219 et. seq. itself (self interest) are rational from each party. The question is whether the desire of self (self interest) of each party departed from a state that: 1) The same principle of freedom; that is, each party has the same rights against a very broad freedom or the principle of equality; 2) Does the principle of distinction, namely imbalance respective capabilities should be structured so that each party can gain or benefit that needs are met.

Legal principle in pela-gandong alliance based on the reason that the way to know justice is to first know what the principles contained in the initial situation or state of justice. ${ }^{10}$ Legal principle in pelagandong alliance based on the reason that the way to know justice is to first know what the principles contained in the initial situation or state of justice. Karen Lebacqz suggests that the same principles of freedom, assuming that each of the parties themselves there is considerable freedom to establish agreements. John Rawls based on the agreement on Social Contract Theory of Locke and Rousseau. Assuming obtain benefit or fulfillment rests on Kant's theory of the autonomous choices as the basis of ethics. Assuming a way according to Karen Lebacqz, are the simple basic idea but has a way of working that is very complex. ${ }^{11}$

Starting from the idea of the position of each of the parties as set forth above, villages or community that organize pela-gandong alliance themselves seem to have the

10 Michael J. Sandel. (2010). Justice, What's the Right Thing to do?. Published in Penguin Books, page 140.

11 Karen Lebacqz. (2015). Teori-teori Keadilan: Six Theories of Justice, Suplemen: Konsep Keadilan Dalam Kristen. Bandung: Nusa Media, page 50 et. seq. 
freedom to build consensus. It also appears that the parties to the agreement consists between two or three villages. Thus, power of agreement maintained valid only between the parties. Power of agreement does not apply to any other village outside the alliance. According to the author's opinion, lies the weakness of pela-gandong alliance.

The reason is as follows: First, view toward the same position, which applies between the parties in alliance, not by itself looking at people outside the Alliance also has the same position, as between members of pela-gandong alliance. Equal positions against other communities outside the alliance, no more than the nature of honor or respect him as a human being. Second, meeting the needs or interests among members of the alliance at this time is limited to one or two things only. The nature of fulfilling the needs or interests is just ceremonial. Including the need or interest to build a house of worship only. Because, at this time without the aid of wood-molar or other assistance to build houses of worship, each villages receives assistance from the state. Also other needs such as necessities of life, safety needs has been carried out by the state.

Thus, we can conclude that the equality that distributes interest among members of pela-gandong alliance no longer have any meaningful sense in achieving the objective of fulfilling life in the real society today. Relationship of mutual assistance that have real meaning in the past, it is more symbolic. By law can be interpreted that the purpose of the law in pela-gandong alliance not fully achieve fairness, certainty, and benefits that adequate.
The purpose in achieving justice between allied parties is no longer relevant because the character of cooperation ${ }^{12}$ to achieve welfare and security is blurry. Feelings of kinship or of suffering ${ }^{13}$ embodied in the condition of a society that has little relation and limited as in pela-gandong alliance turned into a feeling of kinship and of suffering Indonesian people together. The problems of nation is a burden of state. Therefore the role of meeting the needs of material in the form of welfare and security and comfort of life of each group in the past have turned into state hands. The purpose of the alliance as it was built in the past became blurred.

While the relationship pela-gandong are still visible between villages (so-called "Panas Pela") turned into ceremonial relationships. The characterization of justice to complement the needs is no longer a moral principle between groups. The characterization of justice as a moral principle for each group meet in the past has been turned into a principle of instinctive moral, institutional and symbolic. Instinctive means by instinct that the pela-gandong relationship which done by ancestors should still be maintained.

The extent to which the relationship pela-gandong give meaning, is not revealed at all. Institutional means that certain behaviors in pela-gandong relation that should be run, are no longer practiced. For example, to help maintain the security of Pela village from outsiders. Or together facing common enemy. So, pela-gandong relationship is no longer recognized as a strong institution in relation to helping each other. Symbolical-

\footnotetext{
12 Karen Lebacqz, op. Cit., page 51.

13 Ernest Renan as cited by Sukkarno Abuarera, $O p$. Cit., page 221
} 
ly means forms of inter-country assistance among pela villages at the moment only gives emblem that pela-gandong relatinship in the past should be maintained through ritual or ceremony commemorating the relationship. Substantive meaning of the relationship is not as strong as pela-gandong in the past.

John Rawls, as explained by Karen Lebacqz, emphasizes that society requires a knowledge about principles of the relationship of each person. ${ }^{14}$ At this time, the needs of knowledge about the principles that important to relationships between members of alliances are merely emotional needs. The meaning of fulfillment purpose to the emotional needs is just to keep the formal relationship of pela-gandong. In addition, efforts to make pela-gandong relationship as a force to build peace in times of conflict, seemed quite successful. Other things that contains the value of peace and friendship, which is seen as the needs to maintain the relationship are:

1. Prohibition of mating between the villagers of pela-gandong alliances. Able to resist or to defuse tension in case of sudden friction among the individuals who come from alliances. Generally, the tension caused by each party personally, do not know the village of origin of each counterparty. Usually, immediately after knowing the position of the opposition as pela or gandong the tension resolved itself.

2. Meeting the needs of incidental on demand, or based on the information even without a request. For example,

\footnotetext{
14 Karen Lebacz, Op. Cit., page 52.
}

give emergency food aid when villagers of one gandong alliances are experiencing difficulties. In this case if the villagers of a A village that passes petuanan (can be interpreted together with the indigenous regions) of the village B. Village B has pela-gandong relationship with village $A$, the origin of the people who pass through the land of village $B$. Residents from village A that experienced shortage of supplies, or thirst, may soon ask the citizens of village $B$ in its path, in order to give drink coconut water. This assistance must be met without reward. This assistance shall also be given even when the country is undergoing SASI. ${ }^{15}$

Ronald Titahelu ${ }^{16}$ argued that the needs, reflecting the relationship of rights and obligations in very limited spectrum which does not extend to reach social relations, political and economic. Pela-gandong relationship has no influence in political life. In the local elections or legislative elections, pela-gandong relationship does not have contribution. Likewise there is no exchange of agricultural products between each of the countries that are in alliances. A person who is a villagers of a village $A$ and has place in government. This A officials did not have a special obligation to consider the interests of the village $B$ which the alliance partner of the officials. It most likely can happen

15 Certain periods in each year of people prohibited from taking certain plants. For example, young and also old coconut. Including taking old coconuts that have fallen. SASI period marked by twining leaf young coconut on coconut trees in certain places in the farm or forest. Flagging SASI done with certain traditional ceremony by the indigenous leaders.

16 Ronald Titahelu. (2007). Aneka Masalah Masyarakat Hukum Adat Dalam Pembangunan. Yogyakarta: Deepublish, page 346 et.seq. 
is through a personal relationship ever nurtured. Thus, the same position is not significantly be means for achieving the same benefit could be achieved each party..

John Rawls bases his thesis on the principle of justice as a proportionality (the principle of justice as fairness), ${ }^{17}$ which was created in the real political situation between Kant's concept of freedom and equality. In the end, Rawls concludes that justice becomes a formality, not substantive. ${ }^{18}$ Starting from this thesis, it can be said that alliancesgandong not entirely departed from Kant's concept of freedom and equality.

The principle of freedom just visible in the bonding of alliances. Each village in Pela alliance, basing free desire to form relationships with other countries. This is revealed in the process of pela. Proposals or requests for help, which was filed by the requesting village to villagee were asked to help, just based on the free will of the village requesting and promised by the receiving village.

In contrast to the gandong alliance, the principle of freedom to make an alliance partner is not a basis. Determination to gandong alliance partner is determined by attachment based on the same content. That is, every village that is a member of the gandong alliance declared itself derived from the offspring relationship, although each of the different religions. ${ }^{19}$

17 Ian Ward. (2014). Pengantar Teori Hukum Kritis. Translated by: Narulita. Bandung: Nusa Media, page 79 .

18 Ibid.

19 About the origin of the choice to become pelagandong alliances according to the description of Bartel, influenced by patasiwa-Patalima system. Hatib Abdul Kadir still receive the system patasiwapatalia but Bartel reason to doubt about the choice of different religions.
John Rawls makes the different principle (in this case the different interest) between the parties, as a basis for action. The activities, as requirement for one party to gain greater power, higher status. Fulfillment of interest in gandong alliance is not showing this. Assistance provided one party to another, does not significantly raise living standards pela-gandong couples who receive assistance.

The different principles in this case different interests can only be understood by the concept of Distributive Justice. That is, each party will provide its share at the time required by its alliance partner. Ronald Titahelu refer to it as a "mutual relationship in the limited rights and obligations". ${ }^{20}$ The principle of divergence of interests between the parties for John Rawls is seen as a social injustice. However, in relation to the rights and obligations of pela-gandong alliances, the use of different capabilities between the parties, satisfy the principle of expediency.

Pela of one village (Tihulale) helps wood as a material in the construction of houses of worship (mosques in Kailolo) as pela of another village, reciprocated by helping a ceramic material by Kailolo to its pela village (Tihulale) who built a house of worship (church). Each country has different strengths. Tihulale has a wealth of natural resources such as timber, among others. $\mathrm{Hu}-$ man resources in Tihulale majority working as farmers and others working in offices. Kailolo has a wealth of human resources who mostly work as traders in markets and shopkeepers. Others work as clerks in government offices. Natural resources such as

\footnotetext{
$20 \quad$ Ronald Titahelu. (2014). Op. Cit., page 349.
} 
trees in the forest is not as owned by Tihulale village. Such illustration shows that each party has a different strength. But not because the country is not able to obtain Kailolo wood ingredients. Purchasing power of citizens has exceeded than enough to buy ingredients from wood. Kailolo also does not have the ceramic industry. Instead Tihulale country is not able to buy ceramic materials to build a church. But the provision of balanced mutual benefit between the parties are based on the position of "mutual respect", based on the moral principle that is instinctive, institutional and symbolic".

Legal theory of justice of John Rawls did not affect the relations between the citizens of the villages that are bound to pelaganddong. Pela-gandong relationship not affect the occurrence of changes in social and economic life of each villagers residing in pela-gandong alliance area. In the area of governance, the villagers of one village can not affect villagers of another village who happen to became one of the government officials in decision-making related to subsistence. So also in politics and in the cultural field.

\section{Strengthening Pela-Gandong Relations}

Sukarno Aburaera expressed the opinion of John Rawls that "good society should be able to demonstrate itself as an institution of social partnership in which each party contributes to mutually contribute and mutually promote". Departing from the opinion of John Rawls, below the author put forward ideas on how pela-gandong relationship can contribute significantly in an open and pluralistic society today.
Although currently found weaknesses in pela-gandong, but Michael Sandel argues that the agreement that has been built in the past do not need to be sacrificed. Residents in pela-gandong alliances should not be confused with morals on the one hand, and with the question of liability related to the source of life on the other. Inside the pela-gandong relationship that has been running, contained two main values are regarded as the principle is able to strengthen relationships or alliances today. The second main values or principles are (1) the moral and (2) the relationship of reciprocity in limited rights and obligations. ${ }^{21}$ Inside the pela-gandong relationship that has been running, contained two main values are regarded as the principle is able to strengthen relationships or alliances today.

1. Build a moral in grow relation to fulfill each others' needs, made through the unification of the power of the people in those countries as the Unity of Indigenous Peoples. Leaders of each country leader is the leader of the local Indigenous People. Indigenous People is a unit of society has the constitutional right under section 18B (2) of the Constitution of the Republic of Indonesia Year 1945. The recognition of the rights of Indigenous People in the organic legislation through Act No. 32 of 2004 which replaced by Law No. 23 Year 2014 on Regional Government, has been realized in the Moluca Provincial Regulation No. 14 of 2005 concerning the State Back In Unity of Indigenous Peoples. Maluku Provin-

\footnotetext{
${ }^{21}$ Michael Sandel, Op. Cit., page 142 et. seq.
} 
cial Regulations No. 14 of 2004, followed by Local regulations at the district level in the province of Maluku, which stating the existence of unity of Indigenous People. This indicates the potential strength of Indigenous People to develop themselves in a pluralistic society, particularly in Maluku province, not only in the region of Central Maluku.

2. The limited rights and obligations, developed to be rights and obligations with more meaning for economic and social development and culture. Potential Unity of Indigenous People which consists of various groups of Indigenous People in the islands in Maluku province according to the author's opinion needs to be reunited. The strength of all groups of Indigenous People is possible to be synergized to each others to meet expected goals. John Rawls's theory of justice on the character of justice as a moral principle for each group meet the needs of the parties, can be rebuilt through the reunification of all groups of Indigenous People in Maluku province. The unification of the groups formed Indigenous People need to avoid the instinctive moral principle, institutional and symbolic. Unity of Indigenous People who are united today by the name of the Assembly Latupati Maluku, is seen as a social contract among Indigenous People in Maluku. The purpose of Maluku Latupati Assembly needs to be expanded through a similar mission in the field of economic, social and cultural. Through unification of all Indigenous People Unity, procedural interpretation can be done about the fair chance. It was formulated through the mission. The mission will be the main rule. The core of the mission is "to promote, protect, develop, acquire or achieve the will or interests, and maintain and promote social, economic and cultural Indigenous People in Maluku.

Currently Indigenous People units in Maluku still relies entirely on the country, resulting in loss of Indigenous People's role in meeting the material needs and the safety and comfort of living of each group. Role meet material needs, safety and comfort of living should be returned to Indigenous Peoples. Is not intended that the power of Indigenous People are united in Maluku Latupati Assembly will rival or oppossing the State Government and Local Government both at the provincial and district/city. Assembly Latupati Maluku will tell you what it takes to fulfill its needs.

John Rawls emphasizes that the parties need a better life, should be viewed as a basic institution. This basic institutions should be the focus of justice ${ }^{22}$. Indigenous communities in Maluku incorporated in Maluku Latupati Assembly together will constitute the focus of the justice. Assembly Latupati Maluku speak its justice needs to the state. During this time, the demands of justice in Maluku more voiced by politicians, intellectuals and NGOs. Just some time past appeared sound rejection of the Assembly Latu-Pati Maluku, Bonifaxius Silooy, regarding to the planned placement of migrants in Maluku followed

\footnotetext{
$22 \quad$ Ibid. page 51 .
} 
by regrets of Maluku Governor. ${ }^{23}$ It showed two things: (1) Assembly Latupati Maluku began to realize their in a democratic society; (2) The Government shows the opposite stance; the dominance of the state still does not want the role of Indigenous People in a unit called the Assembly Latupati Maluku.

Conflicts of interest between the state and indigenous people, encouraged indigenous people need to develop a more meaningful cooperation. Not only moral bond is instinctive, institutional and symbolic. Instead, the state should be open to Indigenous People and open the door of mutually beneficial cooperation between countries with Indigenous People in Maluku. In this situation, it seems a justification for the statement of John Rawls, that society (in this case the Indigenous People) became the focus of justice.

Although the view of John Rawls as expressed by Sukarno Aburaera above, that the "good society should be able to show itself as an institution of social cooperation in which each party trying to mutually contribute and mutually promote," but the relationship between the state and Indigenous People is not the relationship between social institutions. State not a social institution. State power is an organization of all the people. The presence of the state as an organization of power of all the people, among others, is "to promote the general welfare". Thus, the executive has the function of promoting the general welfare.

For John Rawls, the basic institutions of a democratic society, are essential condi-

23 Source: http://www.cotanane.com "Gubernur Maluku Sesalkan Pernyataan Latupati Tolak Transmigrasi”. Accessed April 21, 2015. tions for a constructive dialogue. Constructive dialogue is essential to organize mutual relations and advancing mutual contribute. In this sense it can be considered that the Indigenous People in Maluku were united in Maluku Latupati Assembly is one of the basic institutions. Basic institutions Latupati Assembly Maluku still instinctive, institutif and symbolic purposes in the field of culture. Nevertheless instinctive nature, institutif and symbolic way was developed as a "alliances-gandong" more advanced moves also in the social and economic.

The unification of all the unity of Indigenous People in Maluku in the Assembly Latupati Maluku, and together declare its will to the state, did not violate the constitution, particularly Article 18B paragraph (2), $28 \mathrm{~A}$, and 28C paragraph (2) of the Constitution of the Republic of Indonesia 1945.

Facing an open relations with community groups from outside Maluku, Ronald Titahelu argued that the values of fraternity and equality in pela-gandong alliances can and should be extended to these groups. ${ }^{24} \mathrm{But}$ the weakness of Ronald Titahelu's view is not mention of how the values of fraternity and equality that developed into the structure of the people and the nation of Indonesia. Another deficiency of Ronald Titahelu statements are, how widespread it may be a way for the achievement of the benefit to pela-gandong alliance.

Adhering to the opinion of John Raw1s, the authors argue that making Indigenous People, in this case, pela-gandong alliances were expanded as one of the basic institutions in a democratic society in Indonesia, is

\footnotetext{
24 Ronald Z. Titahelu, Op.Cit., page 277.
} 
the answer to the first deficiency. As a basic institution that puts brotherhood and equality among all parties, opened opportunities for dialogue. Opportunities to engage in dialogue is possible because of the principle of deliberation. John Rawls requires dialogue between the parties to obtain substantive justice. This is the answer to the second issue.

Implementation of the process of dialogue between alliances-gandong expanded with a country that experiences produce substantive justice. ${ }^{25}$ Constructive dialogue is essential to organize mutual relations and advancing mutual contribute. On the other hand, the internal relationship between pelagandong alliances expanded in Latupati Assembly Moluccas, bound by a common mission. Mission achieved through mutual agreement. The similarity of this mission into their basic rules. The similarity of such a mission on which the efforts to reach the needs of each party.

The similarity of missions that need to be achieved, is a principle that is not in line with the principle of Utilitarians. The Usefulness theory of Utilitarians is the result of a calculation "many benefits for people as much as possible." Therefore, ignoring the small group is a part that must be done by the tribe utilities. While the benefit of all parties is the result of joint efforts.

\section{CONCLUSION}

Local culture Pela-Gandong in the form of an alliance between the two villages or more, has not been able to ensure the achievement of expediency, legal certainty and fairness widely. The nature of pela-gandong alliance

25 Ian Ward, Ibid. that exist today, it is still to be instinctive, institutional and symbolic. Even though there has been an institution called the Assembly Latupati Maluku, but this new institution is limited to only the cultural aspects. However, in the pela-gandong alliance found positive principles as follows': a) Equal status among all the parties based on the autonomous status of each party; b) Equal opportunity for cconstructive dialogues for all parties; c) Build an agreement to meet their individual needs based on ethical and moral; d) The agreement, is structured as a joint mission which has a legal binding power, then affirmed the spiritual and religious aspects; e) The strength of legal agreements that spiritual and religious, the basis for moral action or actions between the parties; f) The presence of pela-gandong alliances expanded through Latupati Assembly Maluku, is a constitutional right guaranteed in Article 18B paragraph (2) of the Constitution of the Republic of Indonesia Year 1945; g) The objectives to be achieved and the role that pela-gandong alliances expanded through Latupati Assembly Maluku, is guaranteed in Article 28A and 28C paragraph (2) of the 1945 Constitution of the Republic of Indonesia.

The positive principles of relationships or pela-gandong alliances can be strengthened into principles that living significantly in structure of state inpluralistic and open society today. This can be done in the following way: 1) The meaning of an association or pela-gandong alliances needs to be expanded. In this connection, the presence of Maluku Latupati Assembly can be interpreted as expanded pela-gandong alliances; 2) Strengthening of meaning carried by Pro- 
vincial Regulation and Regulation Maluku regency/city; 3) The constitutional strength of pela-gandong alliances expanded and the achieved objectives guaranteed in Article 18B paragraph (2), Article 28A, and Article 29C paragraph (2) of the 1945 Constitution of the Republic of Indonesia; 3 ) The strength of the relationship between members of expanded pela-gandong alliances, built through the joint mission of all members, which is affirmed by the law, along with spiritual and religious aspects. Missions of expanded pela-gandong alliances, made laws applicable in the territory of indigenous fellowship respectively, and among members of the alliance; 4) The effect of the enactment of the relationship between expanded pelagandong alliances, following the residents of the village's members of expanded alliances, wherever the people are; and 5) Relationship or expanded alliances, serve as the basic institution in society, nation and state.

\section{BIBLIOGRAPHY}

Diter Bartels. (1977). Guarding the Invisible Mountain: Intervillage Alliances, Religious Syncretism and Ethnic Identity among Ambonese Christians and Moslems in the Moluccas. Ithaca, NY: Cornell University.

E. Fernando M. Manullang. (2007). Menggapai Hukum Berkeadilan: Tinjauan Hukum Kodrat dan Antinomi Nilai. Jakarta: Penerbit Buku Kompas.

Ian Ward. (2014). Pengantar Teori Hukum Kritis. Translated by: Narulita. Bandung: Nusa Media.

Karen Lebacqz. (2015). Teori-teori Keadilan: Six Theories of Justice, Suplemen: Konsep Keadilan Dalam Kristen. Bandung: Nusa Media.
Michael J. Sandel. (2010). Justice, What's the Right Thing to do?. Published in Penguin Books.

Ronald Titahelu. (2007). "Pela-gandong Sebagai Mekanisme Membangun Perdamaian: Tinjauian Singkat Dalam "Perspektif Hukum; Ronald Titahelu. (2014). Aneka Masalah Masyarakat Hukum Adat Dalam Pembangunan. Yogyakarta: Deepublish.

Sukarno Aburaera, Muhadar, and Maskun. (2009). Filsafat Hukum. Jakarta: Kencana Prenada Media.

Wasisto Raharjo Jati. (2013). "Kearifan Lokal Sebagai Resolusi Konflik Keagamaan". Jurnal Walisongo, 21(2): 393-416.

\section{Other sources:}

Diter Bartel. Alliances Without Marriage: Exogamy, Economic Exchange, and Symbolic Unity Among Ambonese Christian and Moslems. Available online at: www.nunusaku.com/pdfs/alliances.pdf (Accessed: Sept 9, 2015).

Gubernur Maluku Sesalkan Pernyataan Latupati Tolak Transmigrasi. Source: http://www.cotanane.com (Accessed: April 21, 2015).

Johra Holle. (2007). Peranan "Pela" dalam Memelihara Toleransi Umat Beragama Pasca Konflik di Kecamatan Saparua serta Implikasinya Terhadap Ketahanan Wilayah Kabupaten Maluku Tengah Provinsi Maluku. (Tesis). Yogyakarta: Universitas Gadjah Mada.

Kevin Tuhumury. (2011). Melihat Pela Kawin Antar Negeri Latuhalat dan Allang Dilihat Dari Sudut Teologi Kontekstual. Available online at: http:// goo.gl/qrND7n (Accessed: August 7, 2015). 